\title{
Service quality of online travel agencies in
}

\section{CALABARZON region}

\author{
Monterey, Judylen M. \\ Faith Colleges Tanuana City Batangas, Philippines (jmmonterey@firstasia.edu.ph) \\ Borbon, Noelah Mae D. $\$ \\ Lyceum of the Philippines University Batangas, Philippines (nmdborbon@lpubatangas.edu.ph)
}

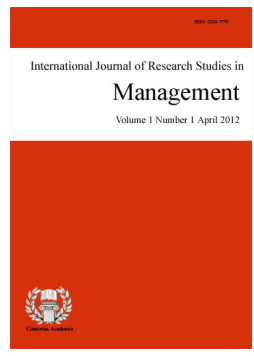

ISSN: $2243-7770$

Online ISSN: 2243-7789

Received: 10 July 2021

Revised: 21 August 2021 DOI: $10.5861 / \mathrm{ijrsm} .2021 . \mathrm{m} 7734$

Accepted: 23 September 2021

OPEN ACCESS

\section{Abstract}

In this study, the service quality of online travel agencies in CALABARZON region in terms of Tangibility, Reliability, Responsiveness, Assurance and Empathy were examined. The OTA's service performance in terms of customer satisfaction and loyalty will be analyzed in order to propose a framework of innovation for the online travel agency. The researcher used the quantitative research design to the 376 OTA employees and customers among the 120 accredited travel agencies operating in CALABARZON IV-A. Based on the model summaries of linear regression for customer knowledge, the Customer Satisfaction and Customer Loyalty are factors that influence Customer Orientation, while Customer Satisfaction, Customer Loyalty and Empathy are factors that influence Interaction Intensity and Service Innovation. Out of this result, the given framework was formulated. It was found out that Female respondents have higher perceptions on service quality and customer orientation, unmarried respondents have significantly higher response on service quality and customer satisfaction and Baby Boomers have significantly lower response on service quality, service performance and customer knowledge of OTA Services. It was recommended for the OTA to support the agent to look out for customers' needs in rendering services. It manifests empathy through sensitivity and they may ensure customer satisfaction by focusing on their wants and needs have a constant feedback monitoring or evaluation.

Keywords: empathy, innovation, loyalty, online travel agency, satisfaction 


\section{Service quality of online travel agencies in CALABARZON region}

\section{Introduction}

Most Online Travel agencies are focusing on providing excellent services and ensuring customer satisfaction based on the performance of the agency, especially customer knowledge, to retain a competitive advantage. The impact of service provider' access to it and integration of customer information on travel agency companies is essential. Online travel agency market forecast of $\$ 756$ billion during 2019 is anticipated to grow by $8 \%$ and hit $\$ 817$ billion by 2020, as reported by Condor Ferries (2020). Overall, the online travel booking market share makes up $63 \%$ of the $\$ 1.2$ trillion the travel industry generates every year. Most people (82\%) booking travel online are doing so using a website or mobile app and prefer to make that booking on a Monday. Given these data, amidst all the global and economic challenges, still the trend in online travel is towards growth, however with the pandemic there might be a massive decrease of travel opportunities. But once the pandemic is gone and everything is normalized, there is a positive expectation on online travel agencies to innovate.

The travel agency collects information about the potential customers' departure and arrival dates, planned destination, time of flight, type of accommodation whether economy or business, and number of passengers if travelling with a group (Ling, et al., 2014). Through the internet, travel agencies gather information about the customers. This happens when they sign-up with the website of the travel agency to inquire about destinations they are interested in. On the other hand, Chiou et al. (2011) reported that most travel agencies have tie-ups with local and international airlines. Thus, they can check what flights the airlines offer and their fares especially discount or promo rates. They can prepare a travel itinerary plus suggested hotel accommodation, to be recommended to the customer. Aside from its income generated from booking of the customer, the travel agency earns from the airline and the hotel.

At the online booking, there is a chance for the agency's travel agent to talk with the customer in case there are queries. At this instance, the customer is provided with additional humanized and customized services in order to win customer's loyalty and positive word-of-mouth endorsement. An attractive feature of an online travel agency is the provision of uncomplicated and secure services. This is also important since tourists and clients of any travel agency would like to avail personalized and customized travel experiences based on their expectations.

In this study, the service quality of online travel agencies in CALABARZON region in terms of Tangibility, Reliability, Responsiveness, Assurance and Empathy will be examined. The OTA's service performance in terms of customer satisfaction and loyalty will be analyzed. In the study conducted by Park et al. (2013), affirms that the quality of OTAs which entice customers to book trips with them. Brick and mortar agencies were patronized by customers due to personal service, accurate knowledge of products and destinations, and fast and flexible service. In contrast, OTAs provided the following innovations: convenience, cheapest price, and, familiarity. Park et al. (2013) studied the dimensions of website quality which were ease of use, security/privacy, information/content, responsiveness, visual appeal and fulfillment. They concluded that ease of use proved to be the most significant dimension of OTA's website quality. This was the choice of respondents, majority of whom were experts on internet use while $45 \%$ had three to six trips two years before the survey. Since, website quality affects not only return intentions and customer satisfaction but also an organization's profits, OTAs must innovate to make their websites attractive to customers and entice them to book their trips.

Customer orientation of the travel agency will be investigated i.e., how it handles its relationship or interacts with the customers. Interaction intensity will be measured in terms of engagement with the customers and assessment of their needs. Customer knowledge co-creation will be examined in two dimensions: knowledge access and knowledge combination. Knowledge access is the extent that information about customer's wants and 
preferences is shared by all the travel agents and managers of the travel agency. Knowledge combination refers to the efforts of the travel agents and managers to be productive as a team in improving the company's products and services to meet the needs of customers. Barriers to booking the services of the travel agency will be examined in the areas of usage constraints, privacy and security barrier, vulnerability barrier, benefit barrier and purchase intentions. How the company strives to attain service innovation will also be probed. Customer orientation, interaction intensity, knowledge access and knowledge combination are factors bringing about service innovation of an OTA. However, risk barrier and value barrier may have negative impact on the customer's intention to book trips with OTAs. Hence, this study will focus on the relationship and effect of customer orientation, interaction intensity, knowledge access and knowledge combination on the service innovation capability of an OTA. On the other hand, the rank and significance of the barriers to customer's purchase intention concerning OTAs will be examined.

This study aims to propose a framework of innovation for the online travel agency and thus assess the customer knowledge, services offered by the OTA and barriers hindering purchase intentions. At this point, the researcher wants to share her inspiration in undertaking this research. Her passion for the hospitality industry deepened as she engaged as chair of the programs - B.S. Tourism and B.S. Hospitality Management at First Asia Institute of Technology and Humanities. With the outlook of deploying students to international practicum, she realized the importance of travel agencies in booking the OTA itineraries.

Further, it is the proper response to advancements in technology and tight competition in the tourism industry. In view of these, there is a need to measure from the viewpoint of OTAs, customer orientation of their services as well as interaction intensity (in terms of OTA's engagement with customers) and the extent of customer knowledge co-creation in the aspects of knowledge access and combinations. These factors will be related to the OTA's service innovation capacity. Barriers to booking the services of OTAs in terms of usage, risk, and value must be examined. There is scarcity of literature on these variables, hence the rationale for this study.

This study aimed to measure the service quality and performance among Online Travel Agencies in CALABARZON Region. More specifically, it aimed to achieve the following objectives. This study aimed to determine the Service Quality of OTAs in CALABARZON region in terms of Tangibility, Reliability, Responsiveness, Assurance, and Empathy. This study also aimed to determine the Service Performance of the OTA in terms of Customer Satisfaction and Loyalty. Moreover, it also aimed to determine the Customer Knowledge of the OTA in terms of customer orientation, interaction intensity and service innovation. This paper determined the significant relationship among Service, Quality, Service Performance, and Customer Knowledge. Finally, based on the results of the study, the researcher will propose a Framework of Innovation for an Online Travel Agency.

\section{Methods}

Research Design - The researcher used the quantitative research design. Moreover, the researcher utilized a triangulation method by interviewing the available managers on duty. A focus group discussion was conducted among the travel agent together with representatives from the OTA's Human Resource Department. The present research also used triangulation method in the conduct of the research and in acquiring supplementary information from the respondents. Triangulation method was defined as "the use of multiple methods or data sources in qualitative research to develop a comprehensive understanding of phenomena" (Lemon \& Hayes, 2020). In the case of the present study, interview and focus group discussions with online travel agency managers, supervisors and rank and file employees were also conducted to further enrich the information gathered.

Participant of the study - The target respondents are from different economic backgrounds inasmuch as travel is undertaken by people from all walks of life for varied purposes. Based on data from the Department of Tourism, there are 120 accredited travel agencies operating in CALABARZON IV-A. The respondents were the 
students, employees, professionals, and businessmen who are customers of OTAs. They were the 25-34 age group in the CALABARZON region IV-A. Respondents were those who have experiences with online travel agencies. The respondents of the study were the travel agents, supervisors, and managers of OTAs. They are the ones who can properly answer the questions on the OTA's customer interaction, interaction intensity, customer knowledge co-creation and service innovation. Survey sessions were held in malls in the six provinces of CALABARZON. These surveys were done after the regular office hours and during weekends.

Data Gathering Instrument - The researcher utilized the modified questionnaire based on the studies of Rosha and Kaur (2015) and Johns et al. (2004) on service quality. For service performance, the study tackled customer satisfaction and customer loyalty by Yang and Peterson (2004). For customer knowledge, this paper focused on customer orientation, interaction intensity, and service innovation as studied by Xie et al. (2020). Four-point Likert scale was also used in the instrument for the respondents to use as a legend: 4 as very great extent, 3 as great extent, 2 as moderate extent and 1 as no extent. The instrument undergone into a content validation and pilot testing where the Cronbach's alpha result for service quality, customer satisfaction, customer loyalty, customer orientation, interaction intensity, and service innovation were 0.95, 0.82, 0.90, 0.692, 0.797, and 0.838 , respectively. The Cronbach's $\alpha$ coefficients and CR were all near or greater than 0.7; therefore, good in the rule of thumb. Thus, this set of questionnaires is considered valid for use

Data Gathering Procedure - Use of google forms via email, to administer the survey facilitated data gathering. Video conferencing was also utilized for those who need to be reached virtually to seek their cooperation in the study. Communications, written and oral, and be employed to arrange a focus group discussion with representatives of OTA employees and their human resource department representatives. When the researcher handled the on-the-job training of the B.S. Tourism and B.S. Hospitality Management students of First Asia Institute of Technology and Humanities, she contacted a travel agency. Personally, she negotiated the approval of the contract with a hotel in Mandaluyong City and requested deployment of students to its Palawan branch. As for the travel agency, it arranged the itinerary, i.e., the booking of flight to and from Palawan, the transportation from the airport to the hotel and vice-versa and the living accommodations to be provided to the trainees. The data gathering lasted for almost three months and was able to gather the identified total sample size.

Data Analysis - The Collation of the accomplished surveys were done to produce an excel sheet for the aggregate data. SPSS was used to derive statistical figures and interpret the results. The correlation and effects of the dependent variables to the independent variable - service innovation was assessed. Weighted mean and rank were used to determine the customer satisfaction and service quality among the online travel agencies. Pearson $r$ was used to test the correlation. While, For the answers in the interview and focus group discussion, thematic analysis was used. In this time of the COVI-19 pandemic, face-to-face interviews with the respondents will be avoided. Identities of the respondents will be held in strict confidence. Participation of the respondents were on voluntary basis and will accomplish an informed consent based on the objectives of this study. Research data gathered were protected and will not be divulged to outside parties. All correspondence during the research process were done honestly and with transparency. Findings of the study were presented fairly, without any bias. All works utilized in the study were listed in References. Also, the researcher manages to seek an approval to use the instrument as to acknowledge the authors of the instrument used in this study.

\section{Result and Discussion}

Table 1 presents the summary of Service Quality, Service Performance and Customer Knowledge. Highest indicator for service quality is assurance (3.46) verbally interpreted as great extent, for service performance is customer satisfaction (3.41) verbally interpreted as agree and for customer knowledge are both customer orientation and service innovation (3.38) verbally interpreted as often.

Service quality is rated as experienced by the respondents to a very great extent under the factor assurance.

94 Consortia Academia Publishing (A Partner of Tourism Educators and Movers of the Philippines) 
It meant that customers feel safe during transactions due to the online travel agency employees' wide product knowledge and the credibility that the online travel agency has the customers' best interests at heart. Thus, the online travel agency won customer commitment and deep loyalty. Service performance in terms of customer satisfaction is rated high. The customers agree that they are satisfied with the services of the online travel agency. It may be attributed to extra care, efforts, and added extraordinary services. Customer knowledge in terms of customer orientation is rated as Often. The online travel agency personnel remain attentive to achieve high customer satisfaction. They render prompt, efficient, and best-in-practice services for the customers. Customer knowledge in terms of service innovation by the online travel agency was rated by respondents as manifested Often. The online travel agency develops new ways of rendering services and innovating travel tours and trip packages. This is in similar with the study of Ocampo et al. (2019) who found out that the responsiveness aspect is found to be the most in need of improvement in terms of providing quality service, with promptness of service being the most significant sub-dimension.

Table 1

Assessment on service quality, service performance and customer knowledge

\begin{tabular}{lcccc}
\hline \multicolumn{1}{c}{ Service Quality } & Composite Mean & Standard Deviation & Verbal Interpretation & Rank \\
\hline Tangibility & 3.37 & 0.13 & Great Extent & 4 \\
Reliability & 3.34 & 0.17 & Great Extent & 5 \\
Responsiveness & 3.43 & 0.11 & Great Extent & 2.5 \\
Assurance & 3.46 & 0.15 & Great Extent & 1 \\
Empathy & 3.43 & 0.48 & Great Extent & 2.5 \\
\hline Service Performance & & & & Agree \\
Customer Satisfaction & 3.41 & 0.43 & Agree & 1 \\
Customer Loyalty & 3.38 & 0.48 & & 2 \\
\hline Customer Knowledge & & & Often & 1.5 \\
Customer Orientation & 3.38 & 0.50 & Often & 3 \\
Interaction Intensity & 3.32 & 0.54 & Often & 1.5 \\
Service Innovation & 3.38 & 0.52 & & \\
\hline
\end{tabular}

Least indicator for service quality is reliability (3.44) verbally interpreted as great extent, for service performance is customer loyalty (3.38) verbally interpreted as agree and for customer knowledge is interaction intensity (3.32) verbally interpreted as often.

\section{Table 2}

Correlation matrix across service quality, customer knowledge and service performance

\begin{tabular}{|c|c|c|c|c|c|c|}
\hline \multirow[b]{2}{*}{ Service Quality } & & \multicolumn{2}{|c|}{ Service Performance } & \multicolumn{2}{|c|}{ Customer Knowledge } & \multirow[b]{2}{*}{ SI } \\
\hline & & Satisfaction & Loyalty & $\mathrm{CO}$ & II & \\
\hline \multirow[t]{2}{*}{ Tangibility } & r-value & $.228(* *)$ & $.172(* *)$ & $.125(*)$ & $.117(*)$ & $.108(*)$ \\
\hline & $\mathrm{p}$-value & .000 & .001 & .015 & .023 & .037 \\
\hline \multirow[t]{2}{*}{ Reliability } & r-value & $.196(* *)$ & $.201(* *)$ & $.165(* *)$ & $.119(*)$ & $.115(*)$ \\
\hline & p-value & .000 & .000 & .001 & .021 & .026 \\
\hline \multirow[t]{2}{*}{ Responsiveness } & r-value & $.175(* *)$ & $.176(* *)$ & $.111(*)$ & .098 & .098 \\
\hline & $\mathrm{p}$-value & .001 & .001 & .032 & .057 & .057 \\
\hline \multirow{2}{*}{ Assurance } & r-value & $.190(* *)$ & $.187(* *)$ & $.166(* *)$ & $.107(*)$ & $.113(*)$ \\
\hline & p-value & .000 & .000 & .001 & .039 & .028 \\
\hline \multirow[t]{2}{*}{ Empathy } & r-value & $.753(* *)$ & $.689(* *)$ & $.620(* *)$ & $.651(* *)$ & $.647(* *)$ \\
\hline & $\mathrm{p}$-value & .000 & .000 & .000 & .000 & .000 \\
\hline \multicolumn{7}{|l|}{ Customer Knowledge } \\
\hline \multirow[t]{2}{*}{ Customer Orientation (CO) } & r-value & $.724(* *)$ & $.667(* *)$ & 1 & $.728(* *)$ & $.689(* *)$ \\
\hline & $\mathrm{p}$-value & .000 & .000 & & .000 & .000 \\
\hline \multirow[t]{2}{*}{ Interaction Intensity (II) } & r-value & $.660(* *)$ & $.628(* *)$ & $.728(* *)$ & 1 & $.737(* *)$ \\
\hline & $\mathrm{p}$-value & .000 & .000 & .000 & & .000 \\
\hline \multirow[t]{2}{*}{ Service Innovation (SI) } & r-value & $.715(* *)$ & $.617(* *)$ & $.689(* *)$ & $.737(* *)$ & 1 \\
\hline & $\mathrm{p}$-value & .000 & .000 & .000 & .000 & \\
\hline
\end{tabular}

*Significant at $p<.05 ;$ Significant at $p<.01$ 
Respondents perceive that online travel agency services have the quality of reliability, to a great extent. Reliability is based upon the completion of promised tasks, perfect mastery of the tasks, timely delivery of services, and accurate execution of tasks. Respondents agree that the service performance of the online travel agency result in customer loyalty. Customers of online travel agency endorse the company to friends and relatives and other people through positive word of mouth. Positive reviews will be circulated by the customer. The customers want to save on time searching for other providers. Thus, they give repeated patronage and contribute higher income to the company. Also, respondents perceive that interaction intensity is often exhibited by the online travel agency personnel. The online travel agency personnel accelerate their acts of engagement with customers. They always have the initiative to ask customers about their needs. The extent of conversations and engagements with the customers is high. The personnel give customers satisfaction through improved products and services. They provide the customer product or service differentiation through their personal touch of online travel agency. Consumers of online travel agency has the top priorities, according to the results of Rangarajan and Krishna (2018) seem to be Loyalty Cards, Equipment, Timely Delivery, Merchandise Quality, Packaging/ Marking, Error-Free Purchases, and Error-Free Home Delivery. Consumer satisfaction is influenced by increased reliability and policy. Gender and age do not appear to influence the perceived or anticipated quality of retail services of online travel agency.

Table 2 presents the Correlation Matrix Across Three Major Variables namely: Service Quality, Customer Knowledge and Service Performance. There is a significant strong positive correlation between service quality and service performance. A significant correlation also exists between service quality and customer knowledge only in terms of customer orientation. However, service quality only has significant correlation with customer knowledge - intensity of interaction only on tangibility, reliability, assurance, and empathy. Customer knowledge, in terms of service innovation has significant correlation with service quality.

Meanwhile, there is a strong positive correlation between customer knowledge and service performance as indicated by the computed $\mathrm{r}$-values which are greater than 0.60 with computed p-values which are less than 0.01 . This signifies that those respondents with higher response on customer knowledge are also those with tendency of giving higher response on service performance. According to Chen et al. (2021), cognitive confidence and knowledge increases people's willingness to reveal information while decreasing their willingness to falsify it, while service performance and affective trust increases both confidentiality and misrepresentation willingness. This study contributes to consumer data privacy by revealing how cognitive and affective trust influence cooperative behavior in different ways, which has important implications towards online travel agency.

\section{Table 3}

Model summary for customer orientation (customer knowledge)

\begin{tabular}{llcrc}
\hline \multicolumn{1}{c}{ Model } & $\mathrm{R}$ & R Square & Adjusted R Square & Std. Error of the Estimate \\
\hline 1 & $.724(\mathrm{a})$ & .524 & .522 & .34772 \\
2 & $.746(\mathrm{~b})$ & .556 & .554 & .33607 \\
\hline \multicolumn{7}{l}{ a. Predictors: (Constant), CSave - Customer satisfaction } \\
b. Predictors: (Constant), CSave - Customer satisfaction; Clave - Customer Loyalty
\end{tabular}

Keeping the customers' best interest at heart, helping customers achieve their goals, getting the customers to discuss their needs, offering the product that is best suited to solve the problem, suggesting the product that would be most helpful to the customer, answering customers' questions about a product correctly, disagreeing with the customers to help them make better decisions, and giving customers an accurate expectation of what the product will do for them. Empathy leads to interaction intensity and service innovation. Interaction intensity increases customer orientation and customer satisfaction which in turn, lead to loyalty (Pansari \& Kumar, 2017). Customer knowledge acquired through customer orientation and interaction intensity leads to service performance, service quality and service innovation (Xie et al., 2020; Enyioko \& Onwusoro, 2014). Customer loyalty to online travel agency is significantly moderated by emotional intelligence. Customer loyalty is often influenced by these service interactions in a partial mediation effect (Prentice \& Nguyen, 2020). 
Model 2 shows the best model fit for customer knowledge in terms of customer orientation as denoted by the computed R-value of .746 (b) which is considered strong positive correlation with computed r-square of .556 which means that customer orientation is explained by 55.6 percent combined scores of Customer Satisfaction and Customer Loyalty. Teng (2019) affirms the finding that customers agree to the service performance of the OTA (in terms of customer satisfaction and customer loyalty), i.e. the OTA personnel are more caring, effort-wise, and rendered extraordinary services. They willingly and freely extend help in case of customer complaints. Customer satisfaction (an aspect of Service Performance) with the services of the OTA and their loyalty (also an aspect of Service Performance) have a significant influence on the degree of customer knowledge gained by the company (Pansari \& Kumar, 2017). Online Travel Agency Employees in a poor service atmosphere showed more frustration and were less likely to give redress to low-status customers than those in a high-status setting, according to the results. Employee responses were less reliant on customer status in a good service environment and converged at a low level of anger and a high likelihood of reimbursement provided (Jerger \& Wirtz, 2017).

\section{Table 4}

Model summary for interaction intensity (customer knowledge)

\begin{tabular}{llccc}
\hline \multicolumn{1}{c}{ Model } & $\mathrm{R}$ & R Square & Adjusted R Square & Std. Error of the Estimate \\
\hline 1 & $.660(\mathrm{a})$ & .436 & .434 & .40617 \\
2 & $.700(\mathrm{~b})$ & .490 & .488 & .38656 \\
3 & $.713(\mathrm{c})$ & .509 & .505 & .38009 \\
\hline \multicolumn{2}{l}{ a. Predictors: (Constant), CSave - Customer Satisfaction } \\
b. Predictors: (Constant), CSave - Customer Satisfaction; EmpAve - Empathy \\
\multicolumn{2}{l}{ c. Predictors: (Constant), CSave -Customer Satisfaction; EmpAve - Empathy; Clave - Customer Loyalty }
\end{tabular}

Model 3 shows the best model fit for the customer knowledge on online travel agency in terms of interaction intensity as denoted by the computed R-value of .713 (c) which is considered strong positive correlation with computed r-square of .509 which means that the interaction intensity is explained by 50.9 percent combined scores of Customer Satisfaction, Customer Loyalty and Empathy. Interaction intensity affects customer satisfaction, customer loyalty and empathy (Xie et al., 2020; Enyioko \& Onwusoro, 2014).

The following acts of the online travel agency personnel show empathy, and the resulting customer satisfaction and loyalty. 1) online travel agency personnel accelerate their acts of engagement with the customers. 2) Employees always have the initiative to ask customers about their needs. 3) The extent of conversations and engagements with the customers is high. Personalization is observed by the online travel agent when rendering the service (Pansari \& Kumar, 2017). The OTA agent grabs every chance to serve the customer. They thinks of the possible needs of the customers based on the company training and his or her experience. Empathy and Customization towards online travel agency, rather than personalization, is more applicable to transaction costs and online group buying, according to this report. Customers, interestingly, place less emphasis on the credibility of an online travel agency when making a purchase. The findings have been explored in terms of their consequences (Hossain, 2019).

\section{Table 5}

Model summary for service innovation (customer knowledge)

\begin{tabular}{llrrr}
\hline \multicolumn{1}{c}{ Model } & $\mathrm{R}$ & R Square & Adjusted R Square & Std. Error of the Estimate \\
\hline 1 & $.715(\mathrm{a})$ & .511 & .510 & .36285 \\
2 & $.734(\mathrm{~b})$ & .538 & .536 & .35307 \\
3 & $.737(\mathrm{c})$ & .544 & .540 & .35156 \\
\hline a. Predictors: (Constant), CSave & & \\
b. Predictors: (Constant), CSave, EmpAve \\
\multicolumn{2}{l}{ c. Predictors: (Constant), CSave, EmpAve, Clave }
\end{tabular}


Model 3 shows the best model fit for the customer knowledge in terms of service innovation as denoted by the computed R-value of .737 (c) which is considered strong positive correlation with computed r-square of .544 which means that the service innovation can be explained by the 54.4 percent combined scores of Customer Satisfaction, Customer Loyalty and empathy. According to Rizal et al. (2020) found out that both of our latent constructs of relationship quality have a positive impact on consumers' perceptions of OTA's e-loyalty. The bootstrapping research also supports the importance of confidence and happiness as a major mediator of e-loyalty. Limitations and possible research proposals are also debated and noted.

Customer knowledge in the area of service innovation is caused by customer satisfaction, customer loyalty, and empathy. Satisfied customers want the continued progress of the online travel agency; thus, they remain loyal customers and in turn, receive special attention from the online travel agency (Enyioko \& Onwusoro, 2014). Customer knowledge is important because it allows online travel agency to better understand how customers define service and product quality. It is easier to know how to satisfy a customer if customer knowledge can be recognized. Customer satisfaction that brings about interaction intensity is generated by the new customer-focused practices. Customer satisfaction leading to interaction intensity is the client's belief that the online travel agency adopts radical service improvements and new ways of rendering its services (Xie et al., 2020). Customer loyalty caused by personalization of online travel agency services drives interaction intensity. Empathy, as shown by the efforts of online travel agency teams to collaborate in providing new approaches to address customer needs, influences interaction intensity. The findings show that online travel agency can attract new and returning customers based on the content of their websites, while hotels can attract repeat customers based on perceived value. On the other hand, the quality of online travel agency website service has a negative impact on the intention to rebook via hotel websites, and there is a negative relationship between the intention to rebook via online travel agency and hotel websites (Chang et al., 2019).

Based on the model summaries of linear regression for online travel agency customer knowledge, the Customer Satisfaction and Customer Loyalty are factors that influence Customer Orientation, while Customer Satisfaction, Customer Loyalty and Empathy are factors that influence Interaction Intensity and Service Innovation. Out of this result, the given framework was formulated

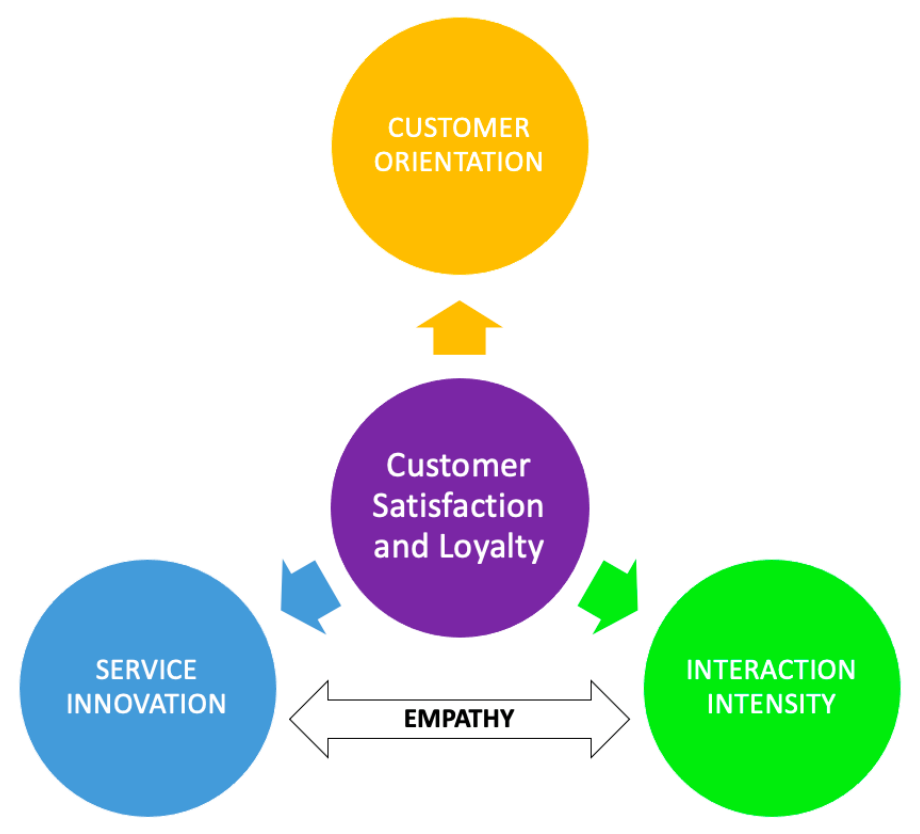

Figure 1. Framework of Innovation for an Online Travel Agency

As seen in the figure, Customer Orientation is in orange. Since it promotes rejuvenation, communication, and positivism. This color also enhances extraversion, allowing people to let go of their inhibitions and express 
themselves more freely. Interaction Intensity is in green. Service Innovation is in Blue. It is associated with a calm serenity over intensity or passion. When asked to visualize a tranquil scene, chances are people will immediately imagine a great deal of blue - usually in the form of a still body of water. Thoughtful and still, blue represents a sense of inner reflection that flows into adaption to change and innovation. A great deal of research has indicated that this impact on the body is indeed inverse to red's, resulting in lower heart rates and even slower metabolisms. Lastly, Customer Satisfaction and Loyalty is in Violet. True to its red parent color, purple is often associated with luxury and power. However, as opposed to red's tendency to reflect the material facets of power and ambition, purple errs towards royalty and nobility.

The willingness of customers to continue patronage of the OTA (customer loyalty) may be achieved by concentrating promotions to existing guests. Customer satisfaction and customer loyalty influence customer interaction. Customer interaction happens when the online travel agency aims for an adequate knowledge of the customers' wants for the present as well as how it will change in the foreseeable future to maintain its market share. Customer orientation is a strong determinant of profitability. Customer satisfaction and customer loyalty also have an impact on interaction intensity and service innovation. Interaction intensity promotes a sustainable competitive advantage. Service innovation i.e. implementation or creation of new services by the OTA help boost the company's bottom line. Customer satisfaction and the acquired customer loyalty have significant influence on efforts toward customer orientation. Customer satisfaction and the acquired customer loyalty have significant influence on interaction intensity (Pansari \& Kumar, 2017; Xie et al., 2020).

Customer satisfaction and customer loyalty have significant effects on improvements of services or service innovation (Xie et al., 2020; Enyioko \& Onwusoro, 2014). Empathy or sensitivity to customer's needs has a significant influence on interaction intensity and service innovation (Xie et al., 2020). This act for empathy to customers will bring about interaction intensity and service innovation. Interaction intensity refers to increasing acts of engagement with the customers and providing online travel agency customers with product and service differentiation which would become the company's competitive advantage.

Service innovation results from interaction intensity i.e., bringing about product and service differentiation giving a possible sustainability of competitive advantage. In the market chain, the customer is extremely important. To put it another way, satisfied customers are the ones who open the door for new customers. Existing customers who are satisfied with the product and service are more likely to recommend it to new customers. This will result in a greater number of customers and the ability to maintain a high level of online travel agency customer relationship.

The intensity of interactions is driven by customer loyalty, which is fueled by the personalization of online travel agency services. Empathy influences interaction intensity, as seen by online travel agency teams' efforts to collaborate in offering novel techniques to fulfill client needs. Customer empathy boosts positive impact on customer satisfaction, resulting in more "symbiotic experiences." Customers who are empathic are also more likely to react to a dissatisfying experience with "forgiveness," implying that consumer empathy can alleviate the negative effects of customer disappointment on customer loyalty. (Wieseke et al., 2012).

Maintaining and expanding corporate client bases requires high-quality service. The findings show that assurance, empathy, and tangible are in great extent to customer satisfaction in the online context. This finding emphasizes the importance of providing caring and individualized attention, protecting individual privacy, and securing business transactions in increasing customer satisfaction, as well as cultivating a strong culture of promoting client-centered services and allocating resources to ensure service counselors have the knowledge and skills they need to provide quality services.

Travel agencies must manage their services provided, especially customer knowledge, to retain a competitive advantage. The impact of service provider' access to it and integration of customer information on travel agency companies is essential. Only in terms of customer orientation, there is a considerable association between service excellence and customer knowledge. Service quality, on the other hand, is only related to 
customer knowledge - the intensity of engagement is only related to tangibility, reliability, assurance, and empathy. In terms of the service innovation, customer knowledge has a strong link to service excellence. In the face of shifting consumer trends, online travel agencies are looking for new revenue streams.

Travel agents can now research, book, and confirm travel online thanks to technological advancements. Agents no longer need to keep hard-copy client files, and they don't have to spend as much time collecting payments from clients and remitting balances to vendors. Getting the most out of what you already have - It's not just about coming up with a new product or service to sell; you also need to focus on improving your existing business procedures in order to increase efficiency, find new customers, increase profits, and reduce waste. When you are constantly innovating and improving your business practices, you are more likely to attract better employees and retain more of your current ones. In the long run, this is harmful to your company's health and performance. The value of tourism sector and destination innovation, including prevalence of small and medium enterprises and the dynamic interconnected existence of tourism experiences, for the concept and implementation of successful regional and national policy acts (Marasco et al., 2018).

Loyalty cannot be easily determined by simple giving the best of service from the travel agency. It doesn't necessarily mean that once a customer repeated their business to a particular travel agency means they are loyal. But it means more of being satisfied customer from the first encounter to the travel agency and/or personnel. The feeling of being welcomed and showing how the customer are important by showing the personnel empathy to each and every customer, it will become the pointing out towards satisfaction and loyalty. Therefore, empathy for travel agency is very much important in travel agency to meet the customer's satisfaction and loyalty. The goal of every company is to maintain a long-term relationship with its customers and business partners. Customers' needs and demands should be recognized in order to acquire potential customers, and customer satisfaction has a significant impact on the entire business operation. As a result, it is critical for the organization to understand exactly what the customers require and how to gain loyalty.

Finally, customer orientation aids support teams in developing positive relationships with their clients. As a result, consumers are more likely to share their product and business experience with team members to maximize service results. This expertise will assist businesses in developing a reliable and useful consumer knowledge base. Furthermore, customer orientation creates a customer-focused working environment, which could also motivate employees to function effectively and collaborate. It also promotes open communication among team members and collaborative problem solving. Team members are often more likely to collaborate as they share and combine their skills (Xie et al., 2020).

\section{Conclusion and Recommendation}

There is a great extent of service quality among the online travel agencies in CALABARZON region especially in terms of empathy. With regards to service performance, the respondents agreed that they are greatly satisfied with the services of the online travel agency. Customer knowledge in terms of customer orientations and service innovation are often observed by the online travel agency customer and employees. The customer satisfaction and loyalty are factors that influence customer orientation, while customer satisfaction, empathy and customer loyalty are factors that influence interaction intensity and service Innovation. A framework of innovation for the Online travel agency was proposed based on the result of the study. The Online Travel Agency may support the agent to look out for customers' needs in rendering services. It manifests empathy through sensitivity. Customer may engage with the Online Travel Agency and suggest innovations in its services which will redound to the customers' benefit in the long run. The company improve its customer service by implementing a feedback system, staff training, and running a regular advertising campaign to attract new customers and keep existing customers informed. Philippine Travel Agencies Association or PTAA may conduct a webinar emphasizing on empathy of the travel agency and innovation on the product and services. The Department of Tourism may organize conferences among Online Travel Agency at the regional level so that a synergy for the improvement of services can be reached to boost tourism. The future researcher may conduct 
further studies referring to the challenges and opportunities in online travel agency since the study is limited only on Service Quality, Service Performance, and Customer Knowledge.

\section{References}

Chang, Y. W., Hsu, P. Y., \& Lan, Y. C. (2019). Cooperation and competition between online travel agencies and hotels. Tourism Management, 71, 187-196. https://doi.org/10.1016/j.tourman.2018.08.026

Chiou, W.-C., Lin, C.-C., \& Perng, C. (2011). A strategic website evaluation of online travel agencies. Tourism Management, 32(6), 1463-1473. https://doi.org/10.1016/j.tourman.2010.12.007

Enyioko, N., \& Onwusoro, C. (2014). Customer relationship management and hospitality industry in Nigeria. https://doi.org/10.2139/ssrn.2397245

Hossain, M. A. (2019). Understanding customers' purchase behaviour from online group buying websites: A transaction cost approach. ACIS 2019 Proceedings (p. 58). https://aisel.aisnet.org/acis2019/58

Jerger, C., \& Wirtz, J. (2017). Service employee responses to angry customer complaints: The roles of customer status and service climate. Journal of Service Research, 20(4), 362-378. https://doi.org/10.1177/1094670517728339

Johns, N., Avci, T., \& Karatepe, O. M. (2004). Measuring service quality of travel agents: evidence from Northern Cyprus. The Service Industries Journal, 24(3), 82-100. https://doi.org/10.1080/0264206042000247777

Lemon, L. L., \& Hayes, J. (2020). Enhancing trustworthiness of qualitative findings: Using Leximancer for qualitative data analysis triangulation. The Qualitative Report, 25(3), 604-614. https://doi.org/10.46743/2160-3715/2020.4222

Ling, L., Guo, X., \& Yang, C. (2014). Opening the online marketplace: An examination of hotel pricing and travel agency on-line distribution of rooms. Tourism management, 45, 234-243. https://doi.org/10.1016/j.tourman.2014.05.003

Marasco, A., De Martino, M., Magnotti, F., \& Morvillo, A. (2018). Collaborative innovation in tourism and hospitality: A systematic review of the literature. International Journal of Contemporary Hospitality Management. https://doi.org/10.1108/IJCHM-01-2018-0043

Ocampo, L., Alinsub, J., Casul, R. A., Enquig, G., Luar, M., Panuncillon, N., ... \& Ocampo, C. O. (2019). Public service quality evaluation with SERVQUAL and AHP-TOPSIS: A case of Philippine government agencies. Socio-Economic Planning Sciences, 68, 100604. https://doi.org/10.1016/j.seps.2017.12.002

Pansari, A., \& Kumar, V. (2017). Customer engagement: the construct, antecedents, and consequences. Journal of the Academy of Marketing Science, 45(3), 294-311. https://doi.org/10.1007/s11747-016-0485-6

Park, Y. A., Gretzel, U., \& Sirikaya-Turk, E. (2013). Measuring web site quality for online travel agencies. Journal of Travel \& Tourism Marketing, 23(1), 15-30. https://doi.org/10.1300/J073v23n01_02

Prentice, C., \& Nguyen, M. (2020). Engaging and retaining customers with AI and employee service. Journal of Retailing and Consumer Services, 56, 102186. https://doi.org/10.1016/j.jretconser.2020.102186

Rangarajan, V., \& Krishna, K. T. (2018). Impact of service quality on customer satisfaction special reference to retail outlets in Tamil Nadu. Indian Journal of Public Health Research and Development, 9(12), 174-179. https://doi.org/10.5958/0976-5506.2018.01828.4

Rizal, H., Amin, H., Suddin, L., Sondoh Jr, S. L., \& Ku, C. J. (2020). Relationship quality and e-loyalty towards online travel agency: Social exchange theory perspective. Jurnal Pengurusan (UKM Journal of Management), 58. https://doi.org/10.17576/pengurusan-2020-58-04

Rosha, R., \& Kaur, N. (2015). A study on assessment of service quality by travel agents in the state of Punjab. Retrieved from http://data.conferenceworld.in/ICSTM2/p950-954.pdf

Teng, H. Y. (2019). Job crafting and customer service behaviors in the hospitality industry: Mediating effect of job passion. International Journal of Hospitality Management, 81, 34-42. https://doi.org/10.1016/j.ijhm.2019.03.013

Wieseke, J., Geigenmüller, A., \& Kraus, F. (2012). On the role of empathy in customer-employee interactions. Journal of Service Research, 15(3), 316-331. https://doi.org/10.1177/1094670512439743 
Monterey, J. M., \& Borbon, N. M. D.

Xie, L., Guan, X., Cheng, Q., \& Huan, T. (2020). Using customer knowledge for service innovation in travel agency industry. Journal of Hospitality and Tourism Management, 45, 113-123.

https://doi.org/10.1016/j.jhtm.2020.08.001

Yang, Z., \& Peterson, R. T. (2004). Customer perceived value, satisfaction, and loyalty: The role of switching costs. Psychology \& marketing, 21(10), 799-822. https://doi.org/10.1002/mar.20030 